\title{
Labor and Material Requirements for Housing
}

HoUSING STARTS INCREASED dramatically through the second quarter of 1971, rising almost 60 percent over their level in the first quarter of 1970. Private nonfarm starts for 1971:2 were at a seasonally adjusted annual rate of 1,961,000 units, and in August reached a rate of 2,235,000 units, their highest level in the postwar period. While starts rebounded throughout 1970, their continued strong increases through 1971 have surprised many observers.

The major factors in this surge of homebuilding have been the strength of the demand for housing and the abundance of mortgage money. High rates of household formation and low levels of housing starts have resulted in a continuing drop in vacancy rates over the last five years. The easing of interest rates, especially short-term rates during 1970 and early 1971, helped to revive the flow of savings to commercial banks and thrift institutions. During the first half of 1971, households accumulated deposits at thrift institutions at a phenomenal rate, four and one-half times larger than that during the same time period a year earlier. Preliminary data indicate that, on a seasonally adjusted basis, households were accumulating savings deposits at thrift institutions at an annual rate of $\$ 46.2$ billion. Adding in time deposits at commercial banks raises the accumulation of total savings deposits to $\$ 85$ billion. This increase in savings flows has for the time being eliminated financial considerations as a constraint on the level of residential construction.

Even had the improved availability of mortgage credit been accurately 
foreseen, questions would have arisen about the real resource requirements to build 2 million units and about their availability to the housing industry. To examine the potential bottlenecks in supply, this paper looks at the labor and material requirements to build houses, focusing discussion on an additional 500,000 units. This figure has several advantages: Starts in the second quarter of 1971 were at a rate about 500,000 higher than those in the last two years; thus data developed from this increment may throw some light on the recent buildup. Furthermore, the rate of 2.5 million units, which has been used at times as a desirable target, would mean a further increase of about 500,000 units over the level of the second quarter. But this figure is used only as a measuring rod for developing labor and material requirements and figures based on it can be adjusted easily to some other total.

\section{The Historical Perspective}

The rapid rise in starts from early 1970 is but one example of several dramatic increases, demonstrated in Figure 1. To date the largest and sharpest bulge in the postwar period was in 1949 and early 1950, when the rate rose almost 850,000 units in five quarters. Other sharp gains occurred in 1954, 1958, and 1967. While Figure 1 shows another peak in the first quarter of 1964 , the ascent to it was much more gradual than the others.

With the exception of 1958, all the sharp increases in housing starts began during periods of low aggregate unemployment and, with the exception of 1967, ended during periods of high unemployment. The increase in 1958 was accompanied throughout by high unemployment while the 1967 increase occurred during a period of low unemployment throughout. With the exception of that in 1949-50, all the major expansions in housing starts took place during periods when nonresidential construction was stagnant if not declining.

Price behavior during past rapid buildups of housing starts has varied markedly. As measured by the Boeckh construction cost index for residential structures, the expansions in 1954 and 1958 were accomplished with essentially stable or declining relative prices for new homes. As discussed in more detail below, the Boeckh index tends to overstate the "true" increase in construction costs. Nevertheless, it declined 1 percent during the 1954 expansion in housing starts, and continued to do so 


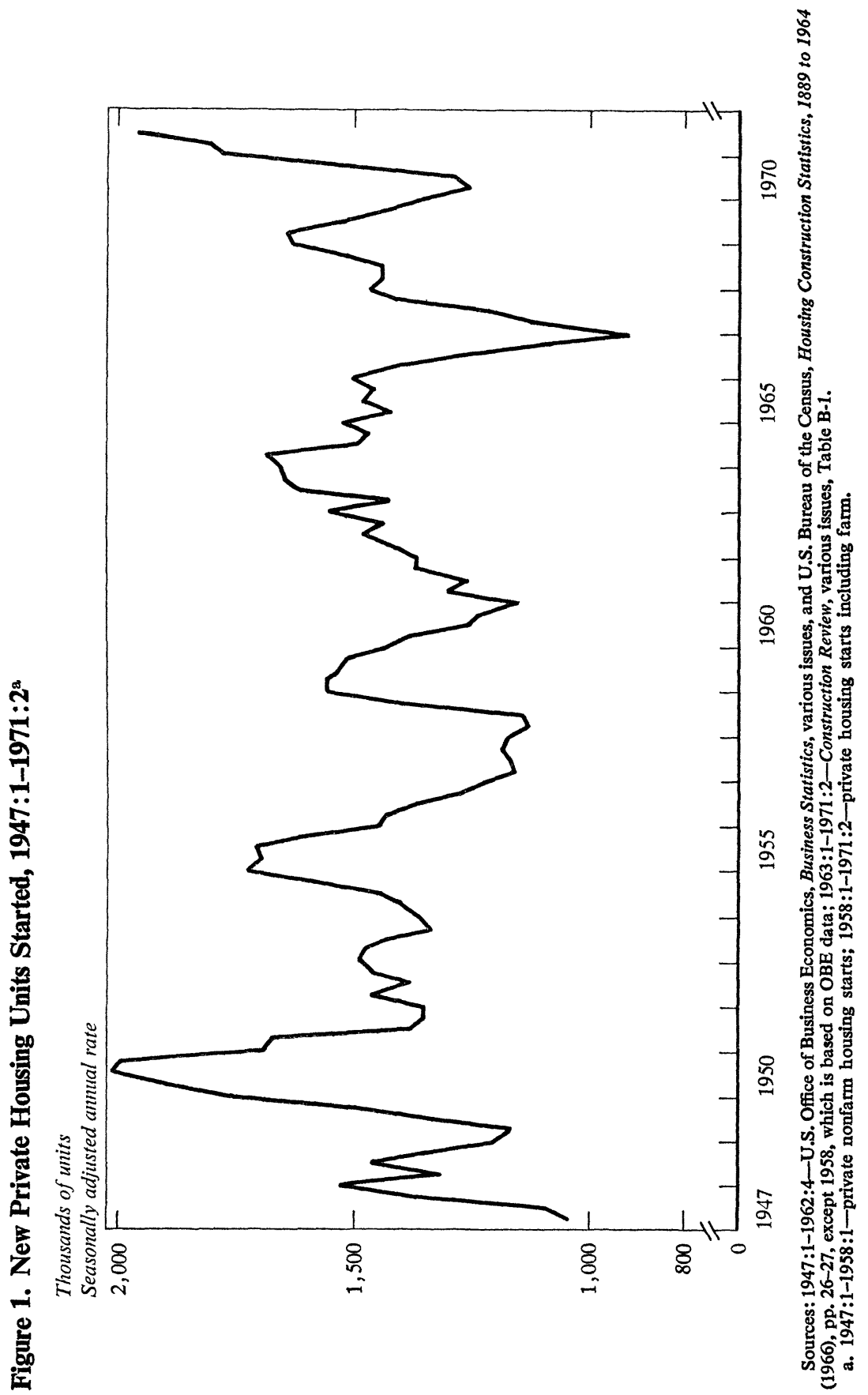


during the quarters immediately following its end. This was at a time when overall prices, as measured by the implicit private nonfarm deflator, rose by 1.9 percent. The 1958 expansion was accompanied by a modest increase in the Boeckh index in excess of general inflation; however, when adjustment is made for the overestimate implicit in the Boeckh index, there appears to have been little movement in relative prices at that time.

The 1949 and 1967 expansions were accompanied by much larger increases in the Boeckh index and in relative prices. Through the period immediately following the 1949 surge in starts, the Boeckh index showed an increase of 4.0 percent in excess of changes in the private nonfarm deflator. In 1967 the excess was 4.7 percent.

There are several reasons for these differences in price behavior. For one thing, the 1954 and 1958 buildups were the smallest of the four. Furthermore, they were set against high or rising unemployment in both the economy as a whole and construction taken by itself. By contrast, the 1967 expansion in starts came at a time of extremely tight labor markets in the aggregate and in construction. While the 1949 expansion took place during a period of rising unemployment in general, nonresidential construction was expanding markedly, and most likely affected adversely the supply of skilled labor on which housebuilding could draw. As seen below, the supply of manpower to residential construction is sensitive to conditions in the labor markets for both the economy as a whole and total construction.

Slack in aggregate and construction labor markets has characterized the 1970-71 expansion. From the first quarter of 1970 through the second quarter of 1971, the Boeckh index rose 2.4 percent in excess of the private nonfarm deflator, although allowance for the overestimate in the Boeckh index would lower this figure somewhat. While more time is needed for the full effect on construction costs, it does appear that the current buildup in houses will be accompanied by an increase in their relative prices, in contrast to the experience of 1954 and 1958. This increase reflects the recent large wage settlements in the building trades and the higher prices of lumber and plywood.

This paper considers in detail the labor, material, and mortgage requirements for building houses and contrasts these requirements with available supplies. The figures presented are projections, not unqualified predictions. They estimate labor and material requirements assuming that units are built with existing technology. If a particular input is in inelastic supply, 
an increase in demand will raise its price and induce someone-a homebuilder or someone else - to reduce his demand and use an appropriate substitute. A prediction would attempt to take account of these effects with appropriate demand and supply elasticities. The value of the projections presented below is in identifying areas where large increases in demand might run into supply bottlenecks.

\section{Labor Requirements}

Labor requirements to build 500,000 housing units are developed by occupation. The basic data come from surveys by the Bureau of Labor Statistics (BLS) of on-site manhour requirements per $\$ 1,000$ of construction cost, by occupation and type of construction. ${ }^{1}$ Extensive surveys on labor requirements were conducted in the early sixties. The BLS is currently engaged in updating these surveys and new data from a survey of singlefamily construction in 1969 have just become available. Recent data for multifamily construction are not available. In fact no survey of apartment construction as such was conducted. Consequently, labor requirements for multifamily structures are based on data for college dormitory construction. A comparison of the two surveys for single-family construction indicates that, with appropriate allowances for changes in productivity and prices, labor requirements derived from the two agree quite closely.

The use of the data on manhour requirements calls for judgments about the distribution of units by type, location, and size. Judgments must also be made about the increases in labor productivity and construction costs over the years since the original surveys. On the basis of recent experience, 55 percent of the half-million starts, or 275,000 units, are assumed to be singlefamily houses, with the remaining 225,000 units in multifamily structures. Both single- and multifamily units are distributed regionally on the basis of 1969 experience. $^{2}$

1. Robert Ball and Larry Ludwig, "Labor Requirements for Construction of Singlefamily Houses," Monthly Labor Review, Vol. 94 (September 1971), pp. 12-14; U.S. Bureau of Labor Statistics, Labor and Material Requirements for College Housing Construction, BLS Bulletin 1441 (1965).

2. As an alternative, starts could be distributed by type and region in proportion to the most recent advance. Such a distribution would make the labor requirement figures more accurate as regards the recent upswing in starts. However, two factors favored the use of levels rather than increments. First, the methodology allows calculation of labor 
The construction cost of a single-family unit is assumed to be $\$ 18,500$ in 1970 dollars, a figure slightly above the actual 1970 average of $\$ 18,325$. The construction cost of a multifamily unit is assumed to be $\$ 12,000$ in 1970 dollars, a bit further above the 1970 figure of $\$ 11,685$. These figures assume little or no change in constant-dollar spending on construction per new unit, or in the "amount" of house per housing unit. A comparison of current-dollar construction costs for privately owned one-unit structures and an adjusted construction cost index for residences reveals an actual decline in the constant-dollar cost of housing units in the last few years. ${ }^{3}$ In fact, from 1969 to 1970 even the current-dollar construction cost figure declined by $\$ 900$ per unit. The trend in cost for multifamily units is not so marked. Constant-dollar costs oscillated around a declining trend from 1964 to 1969; however, they rose substantially in 1970, returning to their 1964 level.

These declines in the amount of real house per housing unit may be a reflection of the introduction of several new programs designed to help families of low and moderate income to buy or rent new housing. Subsidized starts have expanded rapidly in the last few years, and were up from 14 percent of total starts in 1969 to 30 percent in 1970. Some further advance is expected, but the buildup in all starts should mean a constant or slightly declining share for subsidized starts.

The recent drop in the amount of real house per start could also reflect income and price effects. However, given plausible estimates of income and price elasticities, only a slower rate of increase, not an actual decline, is explainable. From 1967 to 1970 the adjusted construction cost index for residential structures rose 16 percent while the GNP consumption deflator rose just over 13 percent, for an increase in the relative price of structures of 2.9 percent. During the same time per capita real disposable income rose 7.9 percent. Most estimates of price and income elasticities of the demand for housing put both in the vicinity of 1 to 1.5 in absolute value. ${ }^{4}$ These figures pointed to an increase in the amount of house per start of 5 to 7.5 percent.

requirements for total private nonfarm starts by multiplying labor requirements for the 500,000 starts by the ratio of total starts to 500,000 units. Second, it is not at all obvious that further increases in starts will follow the most recent pattern; they may well revert to longer-run patterns. In any case, the two sets of weightings lead to very similar results.

3. See discussion of this construction cost index below.

4. See Henry Aaron, "Income Taxes and Housing," American Economic Review, Vol. 60 (December 1970), p. 799, and Frank de Leeuw, "The Demand for Housing: A Re- 
With figures on the size of units one can compute the construction cost of 500,000 units in 1970 dollars. However, to use the BLS survey data on labor requirements, these construction costs were deflated to the year of the relevant BLS survey by indexes based on the Boeckh measures for residences and apartments. These are input cost indexes, calculated by averaging prices for material inputs and labor wage rates. Increases in either material prices or wage rates will cause such an index to rise. However, increases in labor productivity or in the efficiency of material handling are not reflected in reductions in it. In essence these indexes assume that labor productivity and material handling procedures are stagnant. While the Boeckh indexes make some allowance for improved labor efficiency, other evidence suggests that the allowance is inadequate.

For the period 1962-69 the average annual increase in the Boeckh index for residences is 1.8 percentage points higher than that in the Census $\mathrm{Bu}$ reau's hedonic price index for new houses. The hedonic price index assumes the price of a house can be estimated by the price of its components. To estimate the inflation in construction costs, a no-inflation price is estimated using base year prices but current year specifications of the components. This no-inflation price is then compared with the actual current year price to estimate the inflation in construction costs. This procedure is conceptually superior to an input cost measure of inflation. From 1962 to 1969 the increase in the Boeckh index is at an average rate of 4.8 percent per year, while the increase in the Census Bureau index is only 3.0 percent per year. ${ }^{5}$

Additional evidence on the overestimate of construction costs comes from a comparison with the work of R. J. Gordon. Gordon has constructed a price index for all types of structures, allowing for increases in efficiency, which gives a picture for the postwar period markedly different from that presented by the Boeckh index. ${ }^{6}$ From 1947 to 1965 the average annual in-

view of Cross-Section Evidence," Review of Economics and Statistics, Vol. 53 (February 1971), p. 10. These elasticities refer to demand for a stock of houses, measured as the value per unit times the number of units. Thus a household could increase its stock of houses by increasing the valuation or number of units it owns. Data on households and housing units suggest little movement in the number of units per household. Assuming no big boom in second homes, the increased demand for a stock of houses would express itself in more expensive units.

5. Unpublished data collected by the Federal Housing Administration also support the conclusion that the Boeckh index overestimates the annual rise of construction costs of single-family houses. See Robert J. Gordon, "Measurement Bias in Price Indexes for Capital Goods," Review of Income and Wealth, Series 17, No. 2 (June 1971), esp. sec. 5.

6. Robert J. Gordon, "A New View of Real Investment in Structures, 1919-1966," Review of Economics and Statistics, Vol. 50 (November 1968), pp. 417-28. 
crease in the Boeckh index for all structures is 1.6 percentage points more than the increase in the Gordon index for the final price of structures. From 1960 to 1965 the discrepancy is 1.2 percentage points. New price indices for residential structures were calculated by subtracting 1.8 and 1.6 percentage points from the annual movement of the Boeckh indices for residences and apartments.

The product of the number of units and the deflated average construction cost per unit is the total constant-dollar volume of construction of the 500,000 units. Since these added units are to be built in 1971, not the sixties, some adjustment for changes in labor productivity must be made. The Gordon data indicate that labor productivity increased at an average rate of 3.0 percent per year from 1947 to 1965 . From 1960 to 1965, however, the increase was only 1.9 percent per year. The Gordon estimate for 1960-65 agrees exactly with the estimated increase in labor productivity from the new BLS survey of single-family house construction. ${ }^{7}$ The figures reported below are all based on that estimated growth.

The figure of 1.9 percent was used to adjust all labor requirements. Changes in labor requirements and in efficiency may differ for specific skills. Changes in construction techniques or in the characteristics of a typical house may alter the occupation mix of labor. Thus greater efficiency would mean that fewer bricklayers are needed to do the same work but more extensive use of brick in a typical house would increase the need for bricklayers and slow the reduction in labor requirements. Separate rates of decline in labor requirements for each skill class could have been extrapolated from the two studies on single-family house construction. Such a procedure was not followed for several reasons. It was not known whether similar trends applied to the construction of multifamily units and it seemed dangerous to extrapolate on the basis of only two observations. Relative to the 1.9 percent figure, the single-family survey data show a slightly faster decline in total skilled labor requirements as compared with unskilled labor. Thus the estimates presented below may overestimate skilled labor requirements. By specific skills, labor requirements for cement finishers, sheet metal workers, painters, and plumbers have declined most rapidly, while labor requirements for electricians and operating engineers have declined the least.

Tables 1 and 2 present the estimate of 392,500 required on-site man-

7. Ball and Ludwig, "Labor Requirements," p. 13. 
Table 1. On-site Labor Requirements for the Construction of 500,000 Housing Units, by Proficiency Status and Occupation of Worker, 1971

Thousands of manhours

\begin{tabular}{lc}
\hline $\begin{array}{l}\text { Proficiency status } \\
\text { or occupation }\end{array}$ & Requirement \\
\hline All occupations & 392.5 \\
Skilled & 271.6 \\
Bricklayers & 28.8 \\
Carpenters & 113.9 \\
Cement finishers & 9.2 \\
Electricians & 17.5 \\
Ironworkers & 5.7 \\
Operating engineers & 7.1 \\
Painters & 24.0 \\
Plasterers & 8.9 \\
Plumbers & 25.7 \\
Sheet metal workers & 5.3 \\
Other & 25.5 \\
Unskilled & 120.9 \\
\hline
\end{tabular}

Source: Author's estimates based on Table 2 and discussion in text. Figures are rounded and may not add to totals.

hours and the underlying manhour requirements from which it was derived. While the data in Table 1 are in terms of thousands of manhours, most recent estimates of hours worked per year per construction worker suggest that they are also good approximations for the number of men necessary to supply these labor requirements, but not the number of jobs. In a special study the BLS examined the work experience of individual construction workers from union health and welfare fund records in four metropolitan areas, Detroit, Omaha, Milwaukee, and Southern California. ${ }^{8}$ As Table 3 indicates, all workers in skilled occupations averaged about 1,000 hours of work throughout the year.

Other evidence suggests that while a full-time position in construction involves over 1,800 hours of work per year, construction workers average only 1,000 hours of construction work per year. From 1960 to 1967 employment in contract construction times hours of work per week times

8. The advantage of these data is that they measure the experience of specific workers. A disadvantage is that they pertain only to work that was subject to the collective bargaining agreement; construction work not covered, due to type or location of work, is not included. The quality of the data also depends on employer compliance and completeness. Data were collected for 1966 and 1967 and may reflect the general slowdown in construction activity at that time. 
Table 2. On-site Labor Requirements per $\$ 1,000$ Construction Cost for Single-family and Multifamily Housing, by Occupation of Worker, 1960s

Manhours

\begin{tabular}{lcc}
\hline $\begin{array}{c}\text { Proficiency status } \\
\text { or occupation }\end{array}$ & $\begin{array}{c}\text { Single-family } \\
\text { housing }^{\mathrm{a}}\end{array}$ & $\begin{array}{c}\text { Multifamily } \\
\text { housing }^{\mathrm{b}}\end{array}$ \\
\hline All occupations & 50.5 & 91.8 \\
Skilled & 35.7 & 60.6 \\
Bricklayers & 3.0 & 8.9 \\
Carpenters & 18.1 & 16.7 \\
Cement finishers & 1.3 & 1.8 \\
Electricians & 1.6 & 6.0 \\
Ironworkers & $\ldots .$. & 3.4 \\
Operating engineers & 0.9 & 1.6 \\
Painters & 3.8 & 3.6 \\
Plasterers & 0.9 & 1.8 \\
Plumbers & 2.2 & 9.1 \\
Sheet metal workers & 0.7 & 1.3 \\
Other & 3.2 & 6.4 \\
Unskilled $^{\mathrm{d}}$ & 14.8 & 31.2 \\
\hline
\end{tabular}

Sources: Single-family-Robert Ball and Larry Ludwig, "Labor Requirements for Construction of Singlefamily Houses," Monthly Labor Review, Vol.94 (September 1971), pp. 12,13; multifamily-Bureau of Labor Statistics, Labor and Material Requirements for College Housing Construction, BLS Bulletin 1441 (1965), p. 13. Data were adjusted for the regional distribution of starts as discussed in the text.

a. 1969 data.

b. 1960-61 data.

c. Excludes general supervisors, professional, technical, and clerical workers.

d. Unskilled are taken to be laborers, helpers and tenders, and other miscellaneous categories.

Table 3. Average Number of Hours Worked per Year by Construction Workers, by Occupation, July 1966-June 1967

\begin{tabular}{lc}
\multicolumn{1}{c}{ Occupation } & Hours worked \\
\hline Skilled & 1,016 \\
Bricklayers & 1,002 \\
Carpenters & 1,014 \\
Cement masons & 903 \\
Iron workers & 981 \\
Lathers & 1,087 \\
Operating engineers & 1,116 \\
Plasterers & 1,044 \\
Laborers & 660
\end{tabular}

Source: U.S. Bureau of Labor Statistics, Seasonality and Manpower in Construction, BLS Bulletin 1642 (1970), Tables A17-A20. The data are for workers in Detroit, Omaha, Milwaukee, and Southern California. a. Includes only skilled workers listed. 
fifty weeks has averaged 5.652 million manhours. Over the same period social security records indicate that an average of 5.566 million individuals reported earnings in contract construction, for an average of 1,015 hours of work per person. Figures for individual years show only small variation, with a range of 997 to 1,026 hours per person reporting earnings in contract construction. On this basis, the estimated requirement of 392,500 manhours can be translated into 220,000 full-time jobs. Any change in the utilization of existing manpower through an increase in the number of hours worked per year would mean a corresponding drop in the number of men needed to supply the required number of manhours. This gain could be quite large if the existing labor force, not just additional workers, experienced increased hours of work.

How will this heightened demand for labor be met? Special features of the residential construction labor market, combined with current labor market conditions, may help homebuilders to meet possible labor shortages while building 500,000 units. ${ }^{9}$ Homebuilders have traditionally stood at the end of the manpower line. The supply of labor to construction is quite sensitive to aggregate labor market conditions and the supply of skilled labor to homebuilders is sensitive to the availability of other construction work.

Some of these issues are illuminated by the following statistical results.

$$
\begin{gathered}
C L F=-0.11+1.01 C E+2.58 \Delta U, \\
(0.057) \quad(0.200) \\
R^{2}=0.942, \text { standard error of estimate }=0.740 . \\
\text { Figures in parentheses are the standard } \\
\text { errors of the estimated coefficients. }
\end{gathered}
$$

where

$C L F=$ annual percentage change in the contract construction labor force, $1949-70$

$C E=$ annual percentage change in contract construction employment, 1949-70

$\Delta U=$ annual change in the civilian labor force unemployment rate. Aggregate unemployment rates have a strong impact on the size of the

9. The description of the residential construction labor market that follows draws heavily on J. T. Dunlop and D. Q. Mills, "Manpower in Construction: A Profile of the Industry and Projections to 1975," in The Report of the President's Committee on Urban Housing: Technical Studies, Vol. 2 (1968), pp. 239-86a. 
construction labor force, as indicated by the large coefficient on the $\Delta U$ variable. There appears to be a large group of men with construction skills and with high mobility who move in and out of construction in response to job opportunities elsewhere. As labor markets in general tighten, these previously unemployed construction workers find work in other industries; as labor markets loosen, the ease of entry into construction (work forces are being continually formed as old projects are finished and new ones started) results in an increase in unemployment in construction. The coefficient very close to unity on the $C E$ variable reveals that the increases in construction employment that have occurred have attracted labor into the sector almost man for man. This is another indication of the wide dispersion of construction skills and the mobility of these workers. Once these directly induced movements of labor have been accounted for, there is a further substantial flow of manpower into and out of construction in response to changes in other job opportunities. These people presumably have construction skills and would accept construction jobs.

The availability of skilled labor to residential construction is quite sensitive to labor market conditions in construction as a whole. For several reasons-less favorable wages and fringe benefits, shorter duration of jobs, and others-homebuilders have often been forced to accept poorly trained workmen or to find and train new workmen. But they have adapted to their unfavorable position in the manpower line in a way that, given the current labor market situation in both the whole economy and construction, suggests that the residential construction work force could be expanded rapidly and without too much trouble.

Responding to their shortages of skilled workers and their need to train new workers, homebuilders have developed a dual labor force in which a crew of highly skilled workers-keymen -is used to supervise jobs while transitory workmen are hired and trained as needed. Dunlop and Mills suggest that

the task of training a man to do non-key man's work on a homebuilding site is not necessarily long and difficult. Homebuilders often assert their ability to train a good carpenter or machinery operator within a few months. Such training is usually informal, consisting of on-the-job instruction by a more skilled mechanic and work experience. In periods of labor shortage in construction home builders hire and train many persons. ${ }^{10}$

10. Dunlop and Mills, “Manpower in Construction,” p. 245. 
Homebuilders are able to engage in such hiring and training because their work sites are often unorganized or poorly policed by union business agents. Unionization in construction as a whole has been put at between 60 and 70 percent. Industry observers estimate that for single-family construction unionization is perhaps one-half that in total construction. The ability of a homebuilder to retain his keymen is dependent upon labor market conditions in construction as a whole. When construction labor markets are tight, keymen are attracted to other types of construction with higher pay and longer projects.

Because of their adjustment to past labor market conditions, homebuilders are currently in a quite favorable manpower position. Aggregate unemployment and unemployment in construction have both increased markedly from their low levels in 1969 . The seasonally adjusted unemployment rate for private wage and salary workers reporting construction as the industry of their last job averaged 10.7 percent for the first six months of 1971, as contrasted with a rate of 6 percent for the year 1969. On a seasonally adjusted basis, employment in contract construction during the first half of 1971 was $3,246,000$, a drop of 190,000 from employment in $1969 .{ }^{11}$

Data from the household survey, covering individuals without regard to where they work, showed 375,000 unemployed carpenters and construction craftsmen in January 1971. This was an increase of 194,000 over the same figure for 1969. By July 1971 the number of unemployed carpenters and craftsmen had declined to 181,000 , still an excess of 122,000 over the comparable figure for 1969 . The number of unemployed construction laborers followed a similar trend, with an excess over 1969 of 118,000 in January and 34,000 in July.

In an attempt to assess the availability of skilled manpower, estimates of total manhours in construction, by skills, were derived for 1969 and 1970 in a manner analogous to that used to obtain the manpower estimates for 500,000 housing units; that is, figures on real construction activity and

11. Contract construction refers to private establishments performing construction activity-new, maintenance and repair (SIC 15-17). It excludes government agencies engaged in construction activity, operative builders, and force account workers. Operative builders are those primarily engaged in construction on their own account for sale rather than as contractors. In 1967 operative builders had 72,305 employees, compared with $3,341,452$ for contract construction. Force account construction is performed by an establishment primarily engaged in some other business, with its own employees and for its own use. 
on-site labor requirements were used to estimate manhours in total construction for selected skills. ${ }^{12}$ Table 4 compares the decline in manhours in construction between 1969 and 1970 with the manhour requirements of 500,000 housing units for selected occupations. With some exceptions, primarily bricklayers, carpenters, and painters, there appears to have been a rough balance between the amounts of manpower released from the decline in construction activity from 1969 to 1970 and the amounts needed for 500,000 housing units.

Since homebuilding in fact expanded by 500,000 units between 1970 and 1971, the manpower requirements of this recent increase have just about offset the manpower resources released during the decline in overall construction activity between 1969 and 1970. If employment in nonresidential construction had been unchanged between 1970 and 1971, one would expect total construction employment in 1971 to have recovered to its 1969 level. However, employment in contract construction in 1971 is below the 1969 level by almost 200,000, reflecting the continued weakness of nonresidential construction. Real nonresidential construction activity has declined, although dollar expenditures have increased. Current-dollar expenditures for nonresidential construction in June 1971 were, at a seasonally adjusted rate, 5.4 percent above their value for 1970; the Boeckh index of the construction cost of nonresidential structures rose 8.9 percent in the same interval. After adjustment for the overestimate in the Boeckh index, these figures suggest a decline in real activity of about 2.0 percent. This drop in real nonresidential activity, reinforced presumably by increasing productivity, has lowered total employment in contract construction despite the resurgence of homebuilding. Given mid-1971 levels of real nonresidential activity, the increase in total construction employment by 220,000 required for an additional 500,000 housing starts would raise total construction employment merely to 1969 levels. The weakness of the overall labor market would make such an expansion quite feasible.

The estimates in Table 1 of manpower required, by skills, are on a highly aggregative basis and do not guarantee that the regional distribution of unemployed manpower matches the regional increases in housing activity. Advances in starts for the second quarter of 1971 (seasonally adjusted), as contrasted with starts in 1970, ranged from 12.7 percent in the Northeast to 48.4 percent in the West. Starts in the North Central region were up

12. See Dunlop and Mills, "Manpower in Construction," pp. 264-71, for a discussion of a similar calculation. 
Table 4. Decline in Manhours in Construction, 1969 to 1970, and Manhour Requirements for 500,000 Housing Units, by Selected Skills

Thousands

\begin{tabular}{lcc}
\hline Occupation & $\begin{array}{c}\text { Decline in } \\
\text { manhours, } \\
1969 \text { to } 1970\end{array}$ & $\begin{array}{c}\text { Manhour } \\
\text { requirements } \\
\text { for 500,000 } \\
\text { housing units }\end{array}$ \\
\hline Bricklayers & 22.6 & 28.8 \\
Carpenters & 79.1 & 113.9 \\
Cement finishers & 6.7 & 9.2 \\
Electricians & 18.3 & 17.5 \\
Ironworkers & 5.6 & 5.7 \\
Operating engineers & 10.5 & 7.1 \\
Painters & 15.7 & 24.0 \\
Plumbers & 24.0 & 25.7 \\
Unskilled & 107.8 & 120.9 \\
\hline
\end{tabular}

Source: Author's estimates. See text for method.

36.4 percent and those in the South 38.1 percent. To assess possible regional labor shortages requires data on total construction activity by region, but the only such data available report construction activity authorized in permit-issuing places. Table 5 lists the changes in the value of permitauthorized construction from January-May of 1969 to January-May 1971. While these figures do not include public nonresidential construction, they suggest that construction manpower can be expected to be available in the Northeast, North Central, and Western regions of the country, and, depending on the geographical mobility of workers, may be in relatively short supply in the South.

Taken together these figures suggest that manpower is currently available for sustaining the level of housing starts at 2 million units and for facilitating a further expansion. Should nonresidential construction or aggregate activity advance substantially, the supply of manpower to residential construction could be put in jeopardy.

In a recent issue of Brookings Papers, Charles Bischoff presented projections of expenditures on nonresidential structures. ${ }^{13}$ The consensus projection, averaging five alternative models of investment behavior, suggests a depressed level of private nonresidential construction activity through the first half of 1973; in that period, expenditures of $\$ 21.1$ billion (1958 prices)

13. Charles W. Bischoff, "Business Investment in the 1970s: A Comparison of Models" (1:1971), pp. 13-63. 
Table 5. Percentage Change in the Current-dollar Value of Construction Authorized in Permit-issuing Places in the United States, by Region, January-May 1969 to January-May 1971

\begin{tabular}{lcc}
\hline & $\begin{array}{c}\text { Percentage change between } \\
\text { January-May 1969 and } \\
\text { January-May 1971 }\end{array}$ \\
\cline { 2 - 3 } Region & Residential $^{\mathrm{a}}$ & Nonresidential $^{\mathrm{b}}$ \\
\hline Northeast & 6.7 & -15.5 \\
North Central & 10.9 & -0.8 \\
South & 32.6 & 14.7 \\
West & 37.4 & -1.8 \\
\hline
\end{tabular}

Source: Construction Review, Vol. 17 (May 1971, July 1971), Tables C-3, C-6.

a. Private and public housekeeping residential construction.

b. Total private nonresidential construction.

are still below those in the last half of 1970 and well below their peak of $\$ 24.6$ billion in the third quarter of 1969. Even more optimistic forecasts of GNP growth do not reverse the picture of prolonged depressed activity.

So long as aggregate unemployment remains high, the supply of labor to construction in general will be ample. If commercial construction remains at depressed levels, the supply of skilled manpower to homebuilders will be easy and they will have no trouble in holding their keymen.

If, however, the new economic program announced by President Nixon in August 1971 has an immediate large stimulative effect on employment, the supply of manpower to residential construction could be adversely affected. A drop much below 5 percent in the aggregate unemployment rate not only would make it difficult to hire labor to build 2.5 million units, but might also lead to shortages simply in maintaining a 2 million unit rate.

\section{Material Requirements}

To what extent would the pressures implicit in building an increment of 500,000 housing units force up the prices of construction materials? How would this affect the selling prices of houses?

The 1963 input-output structure of the American economy was used to identify industries that sold large proportions of their output to residential construction. The construction of 500,000 housing units gives rise to demand for additional materials not only by the construction industry but also by industries that supply it. To analyze these total requirements, indus- 
tries were ranked by the ratio of total requirements of residential construction to their total output.

Table 6 lists the industries in which more than 5 percent of total output is attributable to the requirements of residential construction. From the first column, which reveals the dependency of particular industries on homebuilding, it is seen to be a primary market for lumber and wood, stone and clay, and fabricated metal products (primarily metal sanitary ware, plumbing fittings and brass goods, heating equipment, and metal doors, sash, and trim). From the second column, indicating the dependence of residential construction on these industries, lumber and wood, stone and clay, and fabricated metal products again appear to be most important, accounting for over 43 percent of material inputs.

What effect would building 500,000 more housing units have on the price and quantity of these material inputs? To answer this question data are presented on recent price and quantity behavior of selected materials. (Lumber and plywood are treated separately in the next section.) Figure 2 depicts output and price indexes for selected material inputs from 1965 to 1970. All prices have been deflated by the wholesale price index for indus-

Table 6. Relation of Selected Industries to Residential Construction, 1963

\begin{tabular}{|c|c|c|}
\hline Industry & $\begin{array}{l}\text { Ratio of } \\
\text { industry output } \\
\text { attributable to } \\
\text { residential } \\
\text { construction } \\
\text { to total } \\
\text { output }\end{array}$ & $\begin{array}{l}\text { Ratio of } \\
\text { direct material } \\
\text { requirements } \\
\text { to total } \\
\text { material } \\
\text { requirements } \\
\text { of residential } \\
\text { construction }\end{array}$ \\
\hline Forestry and fishery products & 14.6 & $\ldots$ \\
\hline Iron and ferroalloy ores mining & 6.5 & ... \\
\hline Nonferrous metal ores mining & 7.3 & $\ldots$ \\
\hline Stone and clay mining and quarrying & 19.8 & 0.5 \\
\hline Lumber and wood products, except containers & 40.5 & 16.5 \\
\hline Household furniture & 8.4 & 2.0 \\
\hline Paints and allied products & 11.2 & 1.0 \\
\hline Stone and clay products & 31.3 & 15.3 \\
\hline Primary iron and steel manufacturing & 6.5 & 2.9 \\
\hline Primary nonferrous metals manufacturing & 9.8 & 2.3 \\
\hline $\begin{array}{l}\text { Heating, plumbing, and fabricated structural metal } \\
\text { products }\end{array}$ & 22.8 & 11.7 \\
\hline Other fabricated metal products & 9.1 & 2.5 \\
\hline Electric lighting and wiring equipment & 12.7 & 2.1 \\
\hline
\end{tabular}

Sources: Derived from U.S. Office of Business Economics, Input-Output Structure of the U.S. Economy: 1963 (1969), Vols. 1, 2, 3. 
Figure 2. Output and Relative Prices of Selected Building Materials, 1965-70

Index $1967=100$
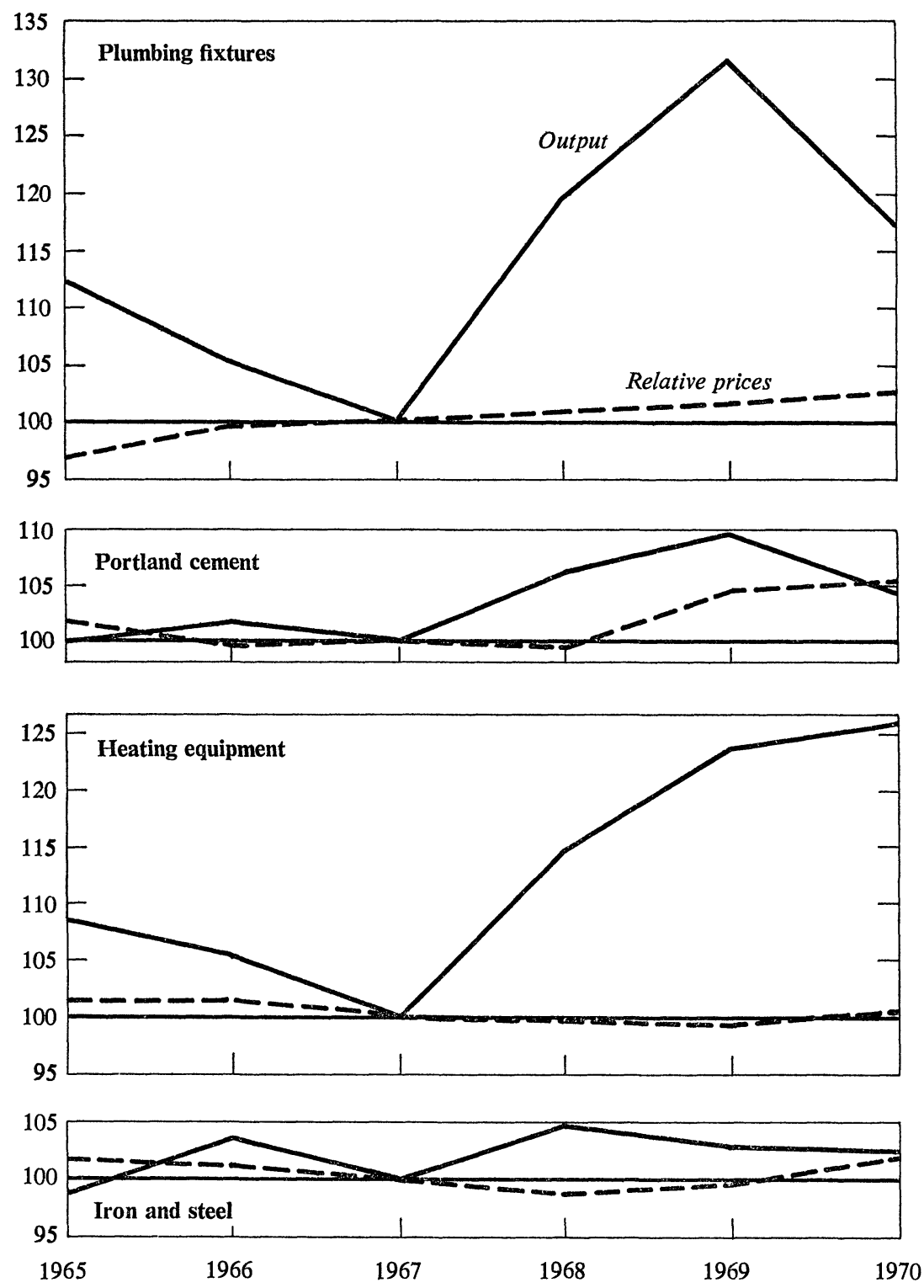
Figure 2. (continued)

Index $1967=100$
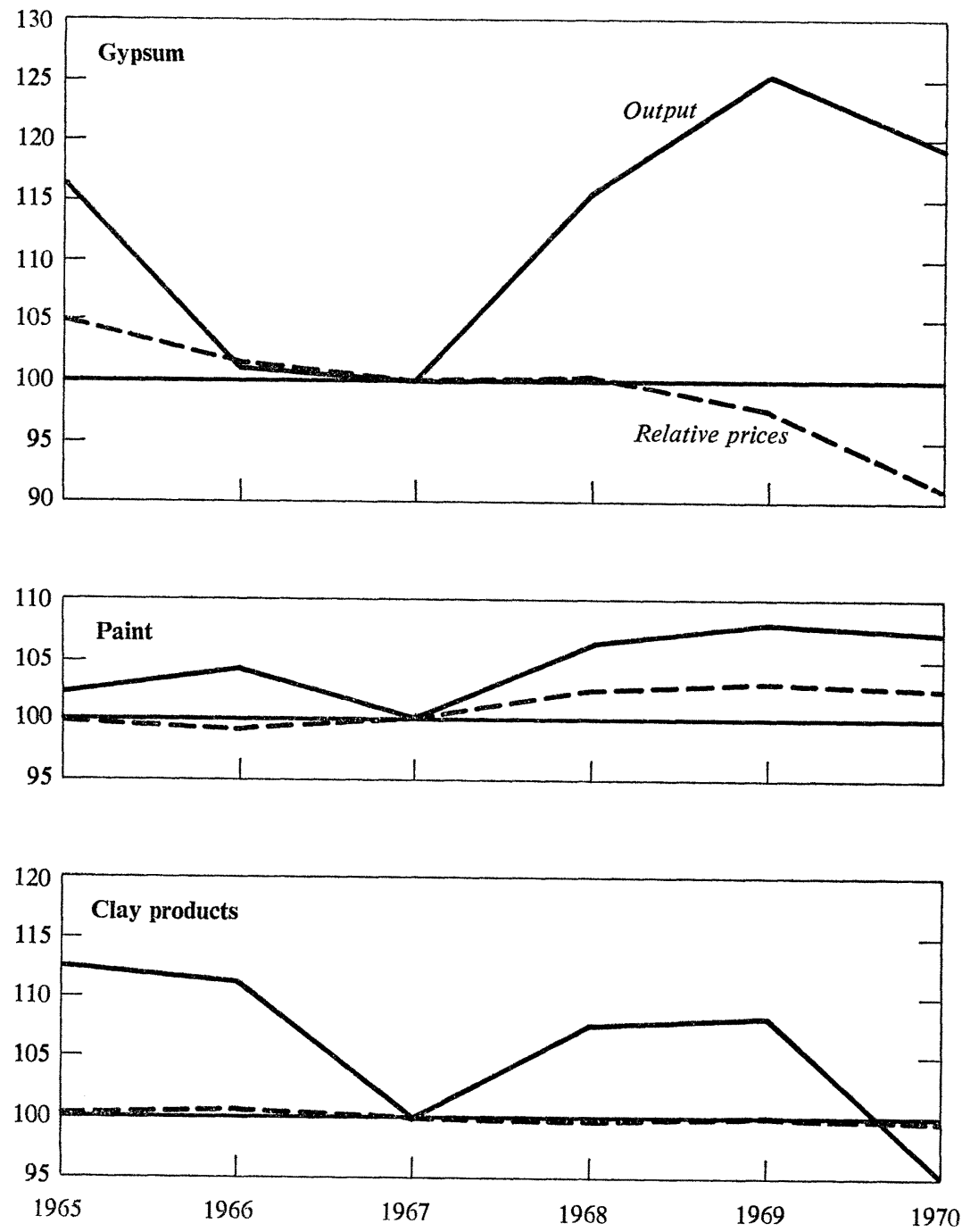

Source: Construction Review, selected issues, Tables E-2 and F-1. Relative prices are calculated by dividing the wholesale price index for the material by the wholesale price index for all industrial commodities. These calculations use the group index, except for iron and steel, whose index was taken as the simple average of structural shapes, reinforcing bars, galvanized sheets, nails, hardware, and steel for buildings. 
trial commodities. The relative price of plumbing fixtures has risen slowly over time with little relation to changes in output; if anything, it rose faster in years when output fell. The relative price of paint has followed movements in output since 1968. The relative price of iron and steel products fell slowly through 1968 and has risen since then in the face of declining output. Cement prices were essentially stable from 1966 through 1968 and have risen since then. Relative prices of other materials, heating equipment, and clay products have been essentially constant, even in the face of large changes in output. The relative price of gypsum goods is falling even as output is rising; this price decline is concentrated in the price of wallboard, which has dropped substantially since 1968 .

Due to the normal lags in construction, the surge in housing starts in 1967 carried over into homebuilding construction in 1968 as well. The attendant substantial increases in output of material inputs, which increased an average of 10.8 percent, are shown in Figure 2. Only for plumbing fixtures, gypsum, and paint were price advances in excess of general inflation and the increase in the relative price of gypsum was only 0.1 percent. Most materials appear to be available in quite elastic supplies.

The price behavior of materials in earlier periods of rapid expansion in homebuilding also supports the conclusion of generally elastic supplies. In 1959, with large increases in the output of materials (apart from iron and steel, output increases averaged over 14 percent), the only advances in relative prices were in plumbing fixtures and clay products. Relative prices of all the other materials declined. Experience in 1963 was a bit more mixed, with relative prices of plumbing fixtures, clay products, and gypsum rising The largest increase was for clay products and was only 0.7 percentage point.

In summary, if one can extrapolate from the record, Figure 2 suggests that, abstracting from price increases due to general inflation, the price of plumbing fixtures can be expected to rise modestly; those of cement and iron and steel may increase slightly more; and that of paint will rise with the increase in residential construction expenditures. Other materials, however, appear to be available in fairly elastic supply.

\section{Lumber and Plywood Requirements}

Lumber and plywood requirements for building 500,000 housing units were developed in much the same way as labor requirements. With the avail- 
Table 7. Lumber and Plywood Required for Housing Construction, 1968

\begin{tabular}{lcc}
\hline \multicolumn{1}{c}{ Material } & $\begin{array}{c}\text { Per } \\
\text { housing } \\
\text { unit }\end{array}$ & $\begin{array}{c}\text { Per } \$ 1,000 \text { of } \\
\text { construction } \\
\text { cost }\end{array}$ \\
\hline Lumber (board feet) & & \\
Single-family & 12,900 & 696 \\
Multifamily & 4,685 & 449 \\
Plywood (square feet) & & \\
Single-family & 4,450 & 240 \\
Multifamily & 2,005 & 205 \\
\hline
\end{tabular}

Source: Author's estimates derived from data in Rising Costs of Housing: Lumber Price Increases, Hearings before the House Committee on Banking and Currency, 91 Cong. 1 sess. (1969).

able data for 1968 on the amount of lumber and plywood used by size and type of dwelling unit, calculations were made of the amount of these materials per unit and per thousand dollars of construction cost (see Table 7).

To use these figures is to assume that the amount of lumber and plywood embodied in each dollar of dwelling unit will remain at its 1968 level. Greatly augmented demand, however, could raise prices and induce some substitution away from lumber and plywood to other building materials. But, as indicated earlier, these figures are intended as projections, not predictions. Recent figures on lumber and plywood use appear to be in line with longerrun trends. Considered in relation to each thousand dollars of construction cost, lumber has shown little consistent movement over the sixties. Plywood has followed a rising trend, although observers feel that much of its potential substitution for other building materials has been accomplished and only more limited areas of substitution remain. ${ }^{14}$

Given the lumber and plywood requirements per unit and the assumptions, laid out above, about the size and type of housing, total requirements for 500,000 housing units are 4.3 billion board feet of lumber and 1.6 billion square feet of plywood. It is not surprising that these numbers represent major increases in output of both materials, for residential construction is a major market for both. From 1962 to 1967 it accounted for an estimated 37 percent of total lumber consumption and probably a similar proportion of plywood consumption. ${ }^{15}$ The lumber to build 500,000 more

14. Dwight Hair and Alice H. Ulrich, The Demand and Price Situation for Forest Products, 1970-71, U.S. Department of Agriculture, Forest Service, Miscellaneous Publication No: 1165 (March 1970), p. 30.

15. First Annual Report on National Housing Goals, H. Doc. 91-63, 91 Cong. 1 sess. (1969), p. 40. 
housing units represents 11 percent of 1970 lumber consumption; for plywood, the corresponding figure is 9 percent.

\section{LUMBER PRICES}

From 1961 to 1970 lumber consumption and prices (deflated by the wholesale price index for industrial commodities) increased in step (see Table 8). Consumption expanded 17 percent and relative prices rose 12 percent. During the winter of 1968-69, lumber prices rose dramatically, as housing starts advanced through 1968, reaching an annual rate of $1,705,000$ units in January 1969. The resulting stepped-up demand for lumber, along with expectations of continued high levels of starts, coincided with some special problems restricting the supply of logs: adverse weather, a boxcar shortage, and some labor shortages. The consequence was a sharp rise in price.

During 1969 and 1970, as housing activity declined and the special supply problems were eliminated, lumber prices fell. The decline began in April 1969 and amounted to 26 percent in the next twelve months.

One contributing factor was action taken in early 1969 by the Nixon administration to increase the supply of lumber and help lower prices. On March 19, President Nixon ordered an increase in the timber cut on public lands- 1.1 billion board feet over the next fifteen months-and announced a cutback of Defense Department purchases. Restrictions on the export of

Table 8. Consumption and Relative Prices of Lumber, 1961-70

\begin{tabular}{ccc}
\hline Year & $\begin{array}{c}\text { Consumption }^{\mathrm{a}} \\
\text { (billions of board feet) }^{\text {Relative price }}\end{array}$ \\
$\begin{array}{ccc}\mathbf{b} \\
(1967=100)\end{array}$ \\
\hline 1961 & 35.522 & 92.2 \\
1962 & 37.313 & 93.9 \\
1963 & 39.173 & 96.3 \\
1964 & 40.842 & 97.6 \\
1965 & 40.963 & 97.5 \\
1966 & 40.695 & 101.6 \\
1967 & 39.150 & 100.0 \\
1968 & 42.038 & 114.4 \\
1969 & 43.048 & 124.1 \\
1970 & 41.432 & 103.4
\end{tabular}

Sources: U.S. Office of Business Economics, 1969 Business Statistics, pp. 43, 46, 149, and Survey of Current Business, Vol. 51 (June 1971), pp. S-8, -9, -31.

a. Domestic production plus net imports.

b. Wholesale price index of lumber divided by wholesale price index of all industrial commodities. 
logs from public lands were also imposed. While the administration's actions could not have had much of an immediate impact on actual lumber supplies, their mere announcement may have served to discourage speculation about continued shortages, and thus to lower prices.

Even more important, the drop in lumber prices reflected the decline in homebuilding activity. The behavior of savings flows and housing starts in early 1969 must have deflated expectations of continued high levels of housing activity. According to the lumber requirements developed above, the actual decline in housing construction between April 1969 and April 1970 implies a drop in the demand for lumber of 2 billion board feet.

The downward movement of lumber prices was reversed by the sharp upturn in housing starts during 1970 and the subsequent surge in construction expenditures. From its low point in June 1970 to June 1971, outlays on new units increased 58 percent to an annual rate of $\$ 31.5$ billion. This higher rate is consistent with an increased demand for lumber of almost 4.5 billion board feet and has been accompanied by an increase of relative lumber prices of just over 18 percent.

The National Association of Home Builders estimates that lumber and wood products account for about 20 percent of the construction cost of a single-family house. A 15 percent increase in the prices of these components would mean an increase in total construction costs of 3 to 4 percent. The effect on the selling price of a house would presumably be less-perhaps 2.5 to 3.5 percent. Certain costs, such as architectural fees and other commissions, would increase as a markup over construction cost, but others, such as land prices, need not rise in response to lumber prices.

\section{PLYWOOD PRICES}

Production of softwood plywood in 1970 was more than five times that in 1950, rising from 2.676 billion square feet to 13.900 billion square feet (see Table 9). The relative price of plywood has fallen off continuously since 1950 except for years of larger-than-average increases in output-years associated with high levels of housing starts. From 1950 to 1960 plywood output nearly tripled while relative prices dropped more than 35 percent. Since 1960 a doubling of output has been accompanied by a decline in relative prices of 13 percent.

The experience of the last few years suggests that the period of expanding output and declining prices may well be over. While output rose 12 percent 
Table 9. Production and Relative Prices of Domestic Softwood Plywood, 1950 and 1960-70

\begin{tabular}{ccc}
\hline Year & $\begin{array}{c}\text { Domestic } \\
\text { production } \\
\text { (billions of square feet })\end{array}$ & $\begin{array}{c}\text { Relative } \\
\text { price } \\
(1967=100)\end{array}$ \\
\hline 1950 & 2.676 & 189.7 \\
1960 & 7.759 & 118.8 \\
1961 & 8.496 & 116.0 \\
1962 & 9.315 & 112.1 \\
1963 & 10.375 & 115.0 \\
1964 & 11.455 & 110.9 \\
1965 & 12.428 & 109.6 \\
1966 & 12.849 & 107.7 \\
1967 & 12.840 & 100.0 \\
1968 & 14.385 & 126.0 \\
1969 & 13.538 & 131.2 \\
1970 & $13.900 \mathrm{p}$ & 103.3 \\
\hline
\end{tabular}

Sources: Dwight Hair and Alice Ulrich, The Demand and Price Situation for Forest Products, 1970-71, U.S. Department of Agriculture, Forest Service, Miscellaneous Publication 1195 (1971), p. 71; and Construction Review, Vol. 17 (May 1971), Table E-2; Monthly Labor Review, Vol. 94 (May 1971), Table 26; BLS unpublished worksheets for indexes prior to 1966.

a. Wholesale price index of softwood plywood divided by the wholesale price index of all industrial commodities.

p Preliminary.

in 1968, relative prices were up 26 percent. Part of this increase was due to a restricted supply of logs. Also, the initial sharp price rise may have generated expectations that stimulated further increases. Yet during 1969, even though plywood prices retreated, they did not return to their level of 1967. They remained above their 1967 level for most of 1970 and increased sharply in early 1971 as housing activity picked up. From NovemberDecember of 1970 to April-May of 1971, the relative price of softwood plywood rose almost 13 percent.

\section{TIMBER SUPPLY}

The major problem involved in an expansion of both lumber and plywood production is the supply of sawtimber, particularly softwood sawtimber. The problem is not that the inventory of trees is too small but that current rates of harvesting are insufficient to meet projected increases in demand at current prices. It has been estimated that the sustainable yield of softwood sawtimber under conditions of intensive management is between 3 and 5 percent of the sawtimber inventory. With an inventory of softwood 
sawtimber of 2 trillion board feet on January 1, 1968, this ratio would mean a sustained yield of 60 billion to 100 billion board feet. These figures on prospective yields are substantially above current rates of harvesting and would require more intensive management of timber lands if they are to be realized on a sustained basis.

Management of timber lands refers to activities such as culling dead trees, pruning and thinning, treatment of disease, seeding and reforesting after cutting, and the maintenance of access roads. More intensive management permits higher rates of growth and thus higher levels of harvesting while the existing inventory is maintained. But it requires the input of real resources, which will necessitate higher prices.

Tables 10 and 11 show the distribution of commercial forest land and sawtimber inventories and cut by ownership. Forests cover 762 million acres out of a total land area in the United States of 2.3 billion acres. Of the total, 235 million acres are classified as unproductive because of low yield; 16 million acres are reserved for park and wilderness areas and are not available for harvesting.

Private holdings are harvested most intensively, with a cut-to-inventory ratio in 1962 of 3.3 percent. Private holdings were supplying 63 percent of

Table 10. Commercial Forest Land and Sawtimber Inventories in the United States, by Ownership, January 1, 1968

\begin{tabular}{|c|c|c|c|c|c|}
\hline Type of forest & $\begin{array}{c}\text { National } \\
\text { forest }\end{array}$ & $\begin{array}{l}\text { Other } \\
\text { public }\end{array}$ & $\begin{array}{c}\text { Forest } \\
\text { industry }\end{array}$ & $\begin{array}{c}\text { Other } \\
\text { private }\end{array}$ & Total \\
\hline \multicolumn{6}{|l|}{ Commercial forest land } \\
\hline Percentage distribution & 19 & 9 & 13 & 59 & 100 \\
\hline Acres (millions) & 97 & 45 & 65 & 303 & 510 \\
\hline \multicolumn{6}{|l|}{ Softwood sawtimber } \\
\hline Percentage distribution & 53 & 12 & 16 & 19 & 100 \\
\hline Board feet (billions) & 1,064 & 233 & 325 & 381 & 2,003 \\
\hline \multicolumn{6}{|l|}{ Hardwood sawtimber } \\
\hline Percentage distribution & 8 & 8 & 14 & 70 & 100 \\
\hline Board feet (billions) & 37 & 38 & 70 & 342 & 487 \\
\hline \multicolumn{6}{|l|}{ Total sawtimber } \\
\hline Percentage distribution & 44 & 11 & 16 & 29 & 100 \\
\hline Board feet (billions) & 1,101 & 271 & 395 & 723 & 2,490 \\
\hline
\end{tabular}


Table 11. Cut of Sawtimber on Commercial Forest Land in the United States, by Ownership, 1962

\begin{tabular}{lccccc}
\hline \multicolumn{1}{c}{ Type of sawtimber } & $\begin{array}{c}\text { National } \\
\text { forest }\end{array}$ & $\begin{array}{c}\text { Other } \\
\text { public }\end{array}$ & $\begin{array}{c}\text { Forest } \\
\text { industry }\end{array}$ & $\begin{array}{c}\text { Other } \\
\text { private }\end{array}$ & Total \\
\hline $\begin{array}{l}\text { Softwood } \\
\text { Percentage }\end{array}$ & 28 & 9 & 35 & 28 & 100 \\
$\quad$ Board feet (billions) & 10.3 & 3.4 & 12.7 & 10.3 & 36.7 \\
$\begin{array}{l}\text { Hardwood } \\
\text { Percentage }\end{array}$ & 3 & 3 & 17 & 75 & 100 \\
$\quad$ Board feet (billions) & 0.4 & 0.4 & 2.0 & 8.8 & 11.7 \\
Total & & & & & \\
$\quad$ Percentage & 22 & 8 & 30 & 39 & 100 \\
$\quad$ Board feet (billions) & 10.8 & 3.8 & 14.7 & 19.1 & 48.4 \\
\hline
\end{tabular}

Source: U.S. Department of Agriculture, Forest Service, Timber Trends in the United States, Forest Resource Report 17 (1965), p. 179.

the softwood cut while holding only 34 percent of the softwood inventory. Softwood inventories are largely concentrated on national forest land, which is being harvested least intensively. ${ }^{16}$ In 1962 softwood timber harvest on all national forest land was only 0.9 percent of the inventory of sawtimber, as contrasted with a harvest rate of 3.7 percent on forest industry land. Indirect evidence suggests that the yield on national forest land has risen to about 1.2 percent of inventory, while the yield on forest industry land has remained at about 3.7 percent. If the former could be raised to match the latter, an additional 26 billion board feet per year would be forthcoming. While such an increase is problematic at best, the Forest Service has stated that "under an accelerated management program that is well balanced in all respects, we could increase timber harvests on the National Forests over 7 billion board feet in the next decade."17 The major problem leading the Forest Service to restrict the harvest on its land is inadequate financing for reforestation, timber stand improvement, and other elements of intensive management. In 1961 the President proposed a ten-year development plan for national forests; in 1970 timber stand improvement and reforestation work were budgeted at 29.5 percent of the level proposed nine

16. Private owners hold almost 60 percent of commercial forest land but only 29 percent of sawtimber inventories. These lands could be stocked more intensively with timber, but this is a long-run, not a short-run, solution.

17. National Timber Supply Act, Hearing before the Subcommittee on Soil Conservaand Forestry, Senate Committee on Agriculture and Forestry, 91 Cong. 1 sess. (1969), p. 16. 
years earlier. ${ }^{18}$ The Forest Service has a backlog of 4.8 million acres in need of reforestation and 13 million acres in need of timber stand improvement. Forest Service estimates indicate these lands could yield 5 billion board feet of timber annually. While there are large differences between estimates by the Forest Service and others about how much of an increase in timber harvesting can be expected from the national forests, it does appear that a substantial increase in timber cutting could be achieved without jeopardizing the multiple-use principle of the national forests.

There is, however, some dispute over how soon increased harvesting of national forest land could begin. Forest industry spokesmen believe that accelerated cutting could begin immediately. The Forest Service is more cautious and has indicated its unwillingness to accelerate cutting before continuing levels of financing are assured and intensive management begins to produce higher yields. It is interesting to note that while projected workload factors for the Forest Service for timber stand improvement and tree planting and seeding rose 51 percent in the 1971 federal budget, they dropped 22 percent in the 1972 budget.

\section{THE PRICE EFFECTS}

What impact would the building of 500,000 more housing units have on lumber and plywood prices? Experience from the early and middle sixties is inappropriate for evaluating the immediate effect on prices of a large increase in demand. The expansion of lumber consumption in that period was over levels of output that had been attained in the fifties; lumber consumption in 1964-66 was at the same level as in 1955 and 1956. But the levels attained in 1968 and 1969 were higher than any others in the postwar period. It may well be that lumber consumption has reached a point at which the short-run supply curve is quite inelastic. The recent rise in starts has been accompanied by large increases in the relative prices of lumber and plywood. An additional jump in starts by 500,000 units would be expected to affect lumber and plywood prices immediately and sharply, raising them by 15 to 20 percent. However, they should moderate somewhat as suppliers respond to them with increased imports, more intensive management of existing lands, and harvesting on new lands, all of which take time to have an impact on supply.

18. Effect of Lumber Prices and Shortages on the Nation's Housing Goals, Report of the Subcommittee on Housing and Urban Affairs of the Senate Committee on Banking and Currency, S. Doc. 91-27, 91 Cong. 1 sess. (1969), p.' 80. 


\section{Mortgage Requirements}

Mortgage requirements for 500,000 housing units were developed from the initial assumptions about unit size and type, along with additional assumptions about inflation, site cost, and loan-to-value ratio. To convert to 1971 prices construction costs originally given in 1970 prices, it is assumed that they are rising by 5.5 percent over the year.

During the first half of 1971, the adjusted Boeckh index of construction costs rose at an annual rate of 7.6 percent. However, several factors suggest that this rate of increase will be moderated in the second half of the year. Higher unemployment and the workings of the construction industry stabilization board would be expected to reduce wage settlements. More importantly, the President's wage-price freeze and subsequent decisions can be expected to moderate increases in construction costs.

Additional elements of the selling price-land and other costs-are assumed to be 25 percent of construction costs for single-family units and 9 percent of construction costs for multifamily units. For single-family units this ratio implies a mean selling price of $\$ 24,432$ in 1970 , which is just above the Census Bureau figure of $\$ 23,400$ for median sales price. The loan-tovalue ratio is assumed to be 72 percent for multifamily mortgages and 79 percent for single-family mortgages. These figures are consistent with recent experience and were used in projections associated with the Housing and Urban Development Act of $1968 .{ }^{19}$

These adjustments, together with the earlier assumptions about the size and number of units, imply gross mortgage requirements of $\$ 6.9$ billion. This figure overstates the necessary net increase in mortgages. The building of 500,000 more units will allow the removal of some additional units from the housing stock that would otherwise have been financed and will thus reduce the net mortgage requirements.

\section{SAVINGS FLOWS}

A net increase in mortgages of $\$ 6.9$ billion would represent a 36 percent increase in home and multifamily mortgage lending over the 1970 level of

19. See Housing and Urban Development Legislation of 1968, Hearings before the Subcommittee on Housing and Urban Affairs of the Senate Committee on Banking and Currency, 90 Cong. 2 sess. (1968), Pt. 2, pp. 1372-73. 
$\$ 19.3$ billion. This is a large increase but not impossible to achieve. Preliminary data for the first half of 1971 place mortgage lending at an annual rate of $\$ 28.6$ billion. The flow of savings to mutual savings banks and to savings and loan associations during the first half of this year can only be characterized as phenomenal. According to preliminary data, savings deposits at mutual savings banks were increasing at a seasonally adjusted rate of almost $\$ 12$ billion during the first half of this year, compared with $\$ 4.4$ billion in 1970. Saving shares and Home Loan Bank advances at savings and loan associations rose at a seasonally adjusted rate of $\$ 26.7$ billion for the first half of this year, far greater than the 1970 increase of $\$ 12.4$ billion. The inflow of time deposits at commercial banks was also at higher rates, but the change was not as dramatic as those of the thrift institutions.

What will these savings flows mean in terms of mortgage lending? Table 12 suggests an answer. It reports the results of multiplying the excess of savings inflows during the first half of 1971 over their rates for 1970 by marginal portfolio percentages. These figures represent the ratio of increased mortgages to increased savings or time deposits over the period 1965-70. The table suggests that the increment in savings flows will mean additional mortgage lending of over $\$ 18$ billion. The figures in Table 12 implicitly assume that savings flows in the second half of the year will remain at the levels observed during the first half. This assumption may seem a bit implausible, especially with respect to savings flows to the thrift institu-

\section{Table 12. Relation of Savings Flows to Mortgage Acquisitions of Savings}

\section{Institutions, 1970-71}

Dollar amounts in billions

\begin{tabular}{|c|c|c|c|c|c|}
\hline \multirow[b]{2}{*}{ Type of institution } & \multicolumn{3}{|c|}{ Savings inflows } & \multirow{2}{*}{$\begin{array}{c}\text { Marginal } \\
\text { mortgage } \\
\text { ratio }\end{array}$} & \multirow{2}{*}{$\begin{array}{c}\text { Potential } \\
\text { increase in } \\
\text { mortgage } \\
\text { acquisitions }\end{array}$} \\
\hline & 1970 & $1971^{\mathrm{a}}$ & Increment & & \\
\hline Commercial banks ${ }^{\circ}$ & $\$ 36.7$ & $\$ 43.9$ & $\$ 7.2$ & 0.157 & $\$ 1.13$ \\
\hline Life insurance companies ${ }^{d}$ & 7.1 & 10.3 & 3.2 & 0.142 & 0.45 \\
\hline Mutual savings banks & 4.4 & 11.9 & 7.5 & 0.510 & 3.83 \\
\hline Savings and loan associations ${ }^{\ominus}$ & 12.4 & 26.7 & 14.3 & 0.900 & 12.87 \\
\hline
\end{tabular}

Sources: Cols. 1 and 2-Board of Governors of the Federal Reserve System, Division of Research and Statistics, "Flow of Funds, Seasonally Adjusted, 2nd Quarter, 1971, Preliminary" (August 6, 1971; processed); col. 4-Flow of Funds Accounts: Financial Assets and Liabilities Outstanding, 1959-1970 (May 4, 1971; processed).

a. Seasonally adjusted annual rate for the first half of the year.

b. Ratio of increased mortgages to increased savings or time deposits over the 1965-70 period.

c. Total time deposits, including large negotiable certificates of deposit.

d. Financial assets minus policy loans.

e. Savings shares plus advances from the Federal Home Loan Banks. 
tions. Some appear to have arisen as part of an adjustment of portfolios away from government securities. Consequently, figures in Table 12 were recalculated on the assumption that all flow variables during the second half of the year will be at one-half their level during the first half of the year. The figures imply an increment in mortgage lending of $\$ 8.6$ billion, still in excess of the $\$ 6.9$ billion requirements.

These figures indicate little problem in financing the most recent increment in starts. Furthermore, other factors may ease the financing of an additional 500,000 housing units. A decline in long-term interest rates should help maintain savings flows to the thrift institutions as well as affect the portfolio allocations of institutions with asset flexibility-commercial banks, life insurance companies, and mutual savings banks. There is good reason to believe that the actual 1970 level of mortgage lending was lower than that which actually could have been attained out of 1970 savings flows. These flows were up sharply over their rates in 1969. The normal lag in the allocation of funds to mortgages means that to some extent 1970 mortgage lending reflected savings flows in 1969, not the higher levels of 1970. For commercial banks and the thrift institutions, the ratio of mortgage lending to deposit inflows for 1970 is below the corresponding figure for the whole 1965-70 period. If mortgage lending by commercial banks is particularly sensitive to time deposits other than large certificates of deposit, there is even more room for optimism, for these deposits have risen even more in 1971 than have total time deposits.

\section{GOVERNMENT ASSISTANCE}

The federal government has been fostering the establishment of several mortgage market innovations, whose further progress during 1971 could facilitate the financing of a high level of housing starts. The innovations include the pass-through mortgage security developed by the Government National Mortgage Association (GNMA) to tap the resources of pension funds, and the secondary market in conventional mortgages being organized by the Federal Home Loan Bank Board, which has budgeted acquisitions at $\$ 1$ billion for 1971. In August 1971 President Nixon authorized an additional \$2 billion for GNMA to use in purchasing FHA and VA mortgages. Finally, continued high levels of mortgage acquisitions by the Federal National Mortgage Association will help to ease the financing of a high level of housing starts. 
In summary, current high rates of savings inflows appear more than adequate to meet the $\$ 6.9$ billion mortgage requirements of 500,000 housing units. Given a decline in long-term interest rates and continued federal support of mortgage markets, funds appear to be available to finance a further increase in housing starts.

\section{Summary and Conclusions}

There should be little trouble from the supply side in sustaining a level of 2 million housing starts in the immediate future. Moreover, there is reason for optimism about the nation's ability to build another large increment of houses. Recent high rates of savings flows to commercial banks and thrift institutions have released financial constraints on homebuilding for the current period. If sustained, these flows, supplemented by aggressive action by the federal government, could finance a further substantial increase in homebuilding.

Labor and most materials appear at the moment to be readily available to homebuilders. The current expansion in homebuilding has occurred at a time of high aggregate unemployment, which works to increase the supply of labor to construction in general, and a time of reduced levels of nonresidential construction, which augments the supply of labor to homebuilding. In the aggregate the requirements for skilled workers in homebuilding appear to be matched by reductions in other forms of construction. Should there be a marked increase in either nonresidential construction or in general economic activity, the availability of labor to homebuilding will be curtailed.

The supplies of most building materials appear to be quite elastic; they expanded in 1968 as well as in earlier housing booms with relatively small movements in relative prices. Lumber and plywood are the major exceptions: As demand for them moves up with the increase in homebuilding, their prices will rise substantially. 


\section{Comments and Discussion}

John Kareken: Craig Swan has given us a very plausible and optimistic assessment of the nation's ability to build 500,000 more houses a year, or $2,500,000$ in total. If anything, I would say the assessment may be a shade too optimistic. For one thing, housing has already risen greatly from its 1970 average and presumably has absorbed a lot of labor in the process. The labor requirements created by the next addition of 500,000 units to housing starts may not be met quite as easily as was suggested in the paper.

Another factor that may not be so favorable is the availability of mortgage money. The flow of funds into the thrift institutions in the first half of 1971 was super-phenomenal; Swan has cut this flow in half in making his projection of funds. While it looks prudent, the assumed cutback may not be large enough. The recent heavy flow of funds into the thrift institutions reflected not just a stock adjustment, but also-at least according to some people-fears about the economy. If the new economic policy alleviates those fears, that incentive for the accumulation of liquid funds will disappear.

The historical analysis revealed a striking contrast between the 1949 and the 1967 increases in housing starts, both of which caused sharp increases in costs and relative prices, and the 1954 and 1958 increases, neither of which had that effect. The 1949 and 1967 increases were larger, but other factors seem important. The ease of the 1954 and 1958 advances may suggest that we should not concern ourselves too much with smoothing house building. There must be some gains from smooth output, but if the same amount of 
housing can be obtained over some time interval, it may not be a bad idea to build the houses when nonresidential construction is weak. In a rough way that is what our rather queer financial arrangements have so far guaranteed. The evidence that Swan has provided suggests that we may not have great cause to worry about smoothing the production of housing.

\section{General Discussion}

Nancy Teeters reported that work she had done to evaluate the reasonableness of the national housing goals revealed that the underlying demand for housing is very strong. Shifting demographic factors, primarily the large increase in the relative number of young people entering the labor force in the marriageable ages, is responsible for this demand. The demand from this source will remain strong for at least five years. Moreover, as these young people start having children, demand will shift back toward singlefamily homes, if past patterns prevail, and there may be some retreat from the relatively high demand for multifamily units that prevailed in the late 1960s.

She felt that the strong underlying demand for housing posed a policy dilemma: Swan's paper supports the informal observation that strong housing demand is usually satisfied only when business fixed investment is relatively weak. If the investment tax credit is again reinstated, the resulting increase in business fixed investment is likely to squeeze residential construction. Given the demand outlook for housing and the unsatisfactory condition of much of the existing housing stock, reinstatement of the investment tax credit may be a very poor policy choice, she concluded.

Charles Bischoff pointed out that there were several ways in which the investment tax credit might indirectly affect residential construction. He reported evidence that the investment tax credit tends to shift business capital spending toward equipment and away from nonresidential construction, other things being equal. To this extent if the real competition for resources comes from within the construction industry, the investment tax credit should not hurt housing.

Another important question has to do with the flow of funds. If the investment tax credit stimulates business capital spending more than dollar for dollar, it will tend to tighten long-term credit markets. Clearly, a loosening of funds would occur in the short run, since the tax credit would begin 
immediately; but its impact would have a substantial lag. In the longer run, the situation would be reversed, according to neoclassical equations that indicate that investment is stimulated more than dollar for dollar over a twoor three-year horizon, and the supply of funds for housing would suffer an adverse effect.

There was some inconclusive discussion of whether particularly strong competition for resources took place between machinery and equipment industries on the one hand, and housing on the other. John Kareken stressed that highways and other public works as well as business construction competed with homebuilding.

Arthur Okun reported the view of senior adviser Alan Greenspan, who was unable to attend the conference, that labor supplies for homebuilding were extremely sensitive to the general state of labor markets. He would emphasize this more strongly than competition with nonresidential construction. While 2.5 million homes might be built in today's labor market, it might be difficult to keep building 2 million houses if the aggregate unemployment rate began to approach 4 percent.

Okun felt that Swan's paper illuminated the supply considerations that permitted, and contributed to, the extreme variability of the industry. Few factors seem specific to homebuilding. The labor force is highly mobile. With the exception of lumber, the materials used by homebuilding are also used widely elsewhere. Unlike manufacturing, no well-defined capacity limitation is set by plant and equipment stocks.

William Poole noted that big shifts in the number of people employed in construction occur without much impact on relative wage rates, suggesting a high elasticity in the supply of labor. This observation implied that the price elasticity of demand must be high also. If the price elasticity of demand were low, presumably activity and employment would remain more stable and wages would rise or fall to the extent necessary to maintain the required labor in home construction. Thomas Juster noted, however, that the large downward swings of activity in the past seem to reflect shortages of financial resources rather than of labor or materials.

Juster reported his general impression that single-family house construction and certain types of commercial building had experienced a very marked shift away from on-site construction to in-factory production. Of course, the rapid increase in mobile homes can be regarded that way, but the trend extends far beyond them. This new kind of factory-built housing probably has substantial productivity gains and flexibility. Its existence fur- 
ther reduces the danger of labor supply shortages for on-site building. At the same time that workers are needed to fill conventional jobs in housing construction, they might be in the process of being released from other kinds of construction activities because of increased industrialized fabrication. Although Juster noted the lack of data on the growth and relative importance of in-factory activity, his general impression was that it was growing rapidly, mainly because of price advantages and the absence of certain types of restrictive labor practices that affect on-site construction.

Craig Swan said that recent surveys would soon make available more information on the relative importance of factory-made housing. The preliminary data support the impression of a marked shift toward prefabrication. The on-site occupational mix has shifted toward unskilled labor, implying increased use of prefabricated parts.

Warren Smith believed that the prospect for a new investment tax credit was one part of a general shift toward an expansionary fiscal policy, including other tax cuts of a permanent nature. When the economy recovers, these cuts will require monetary policy to be tighter than it otherwise would have been. Indirectly, current policy decisions may be generating a situation in which it will become very difficult to finance housing in a prosperous economy.

Thomas Juster felt that, even under such circumstances, housing could compete for funds better than it had in the past. Up through 1966-67, the supply of funds to housing was constrained by the 6 percent usury laws in most states. Many of these usury laws were liberalized subsequently. For the first time in years, a legitimately free market for funds is available to the housing market. In that respect, mortgage borrowing is now more closely akin to Treasury debt and business borrowing. Unlike their situation in the past, mortgage borrowers can compete for funds, paying whatever rates are required. 